\title{
Timing of deposition, orogenesis and glaciation within the Dalradian rocks of Scotland: constraints from $\mathrm{U}-\mathrm{Pb}$ zircon ages
}

\author{
T. J. DEMPSTER ${ }^{1}$, G. ROGERS ${ }^{2}$, P. W. G. TANNER ${ }^{1}$, B. J. BLUCK ${ }^{1}$, R. J. MUIR ${ }^{1,2,5}$, \\ S. D. REDWOOD ${ }^{3,8}$, T. R. IRELAND ${ }^{4,6}$ \& B. A. PATERSON ${ }^{2,7}$ \\ ${ }^{1}$ Division of Earth Sciences, Gregory Building, University of Glasgow, Glasgow G12 8QQ, UK \\ ${ }^{2}$ Scottish Universities Environmental Research Centre, East Kilbride, Glasgow G75 0QF, UK \\ ${ }^{3}$ British Geological Survey, Murchison House, West Mains Road, Edinburgh EH9 3LA, UK \\ ${ }^{4}$ Department of Geological and Environmental Sciences, Stanford University, Stanford, California 94305-2115, USA \\ ${ }^{5}$ Present address: Robertson Research International, Tyn-y-coed Site, Llanrhos, Llandudno LL30 1SA \\ ${ }^{6}$ Present address: Research School of Earth Sciences The Australian National University Canberra ACT 0200 \\ Australia \\ ${ }^{7}$ Present address: Department of Earth Sciences, Wills Memorial Building, University of Bristol, Bristol BS8 1 RJ, UK \\ ${ }^{8}$ Present address: Exploration and Discovery Latin America Inc., P.O. Box 0832-1784, World Trade Center, Panama, \\ Republic of Panama
}

\begin{abstract}
The stratigraphical and structural continuity of the Late Proterozoic Dalradian rocks of the Scottish Highlands is re-examined in the light of new $\mathrm{U}-\mathrm{Pb}$ zircon ages on the tuffs belonging to the Tayvallich Volcanic Formation (601 $\pm 4 \mathrm{Ma})$, and on the late Grampian 'Newer Gabbros' $(470 \pm 9 \mathrm{Ma})$ of Insch and Morven-Cabrach in Aberdeenshire. These age data, together with the existing $590 \pm 2 \mathrm{Ma}$ age for the Ben Vuirich Granite, provide key radiometric constraints on the evolution of the Dalradian block, and the implications arising from these ages are critically assessed. Three main conclusions are drawn.

(1) The entire Caledonian orogeny, although short-lived, is unlikely to have affected sediments of Arenig age and a break probably occurs between those Dalradian sediments of late Proterozoic ( $<600 \mathrm{Ma})$ age and the Ordovician rocks of the Highland Border Complex.

(2) A period of crustal thickening probably affected some Dalradian rocks prior to $590 \mathrm{Ma}$. Such an event is indicated by both the polymetamorphic histories of the lower parts of the Dalradian pile and the contact metamorphic assemblages within the aureole of the Ben Vuirich Granite, which are incompatible with sedimentary thicknesses.

(3) Age constraints on global Late Proterozoic glacial activity also suggest that the Dalradian stratigraphy is broken into discrete smaller units. Models involving continuous deposition of Dalradian sediments from pre-750 Ma to $470 \mathrm{Ma}$ are rejected.
\end{abstract}

Keywords: Dalradian Orogeny, Neoproterozoic, glaciation, U-Pb, zircons.

Understanding the evolution of orogenic belts critically depends upon having reliable geochronological constraints. This is particularly important in Precambrian orogenic belts, which lack fossiliferous successions, and in which interpretations rely only on isotopic ages and correlations with global events. The dating of late orogenic events is relatively straightforward, using $\mathrm{Rb}-\mathrm{Sr},{ }^{39} \mathrm{Ar}-{ }^{40} \mathrm{Ar}$ or $\mathrm{K}-\mathrm{Ar}$ techniques on micas (e.g. Cliff 1985). However, such systems typically only record cooling after the last thermal pulse, and the dating of peak metamorphic and prograde events directly is more difficult (e.g. Vance et al. 1999). An alternative way of constraining the timing of both deposition, and the early parts of orogenic history is to date igneous bodies whose emplacement relative to tectonothermal events can be established (e.g. Long 1964; Pidgeon \& Johnson 1974; Rogers \& Dunning 1991). In these cases, geochronological systems with high closure temperatures, such as $\mathrm{U}-\mathrm{Pb}$ on zircon, must be used in order to minimize effects of resetting by later events.

There is considerable uncertainty in both the age of deposition of the Dalradian sediments in the Scottish Highlands and their subsequent metamorphism (Tanner \& Bluck 1999; Soper et al. 1999; Prave 1999). The accepted stratigraphy of the Dalradian block is presented in Figure 1. Although there is evidence that the Central Highland Division rocks are not part of the 'Dalradian Supergroup' and have experienced a c. $800 \mathrm{Ma}$ orogenic event (Piasecki \& van Breemen 1983; Noble et al. 1996; Highton et al. 1999), the extent to which Precambrian tectonothermal events have affected the 'higher' stratigraphic levels is uncertain (e.g. Phillips et al. 1999). The uppermost boundary of the Dalradian is similarly controversial (e.g. Tanner 1995, Bluck \& Ingham 1997). A single Early Ordovician microfossil specimen is reported to be from the Macduff Slate (Downie et al. 1971; re-examined by Molyneux 1998) but no fossils have been found in these rocks by any later study (Bliss 1977). Some workers use this unconfirmed palaeontological evidence to argue that Southern Highland Group deposition continued through to the Arenig and that the Dalradian rocks were affected by a single shortlived Caledonian orogeny soon afterwards (Soper et al. 1999; Dewey \& Mange 1999). Continued Dalradian deposition into 


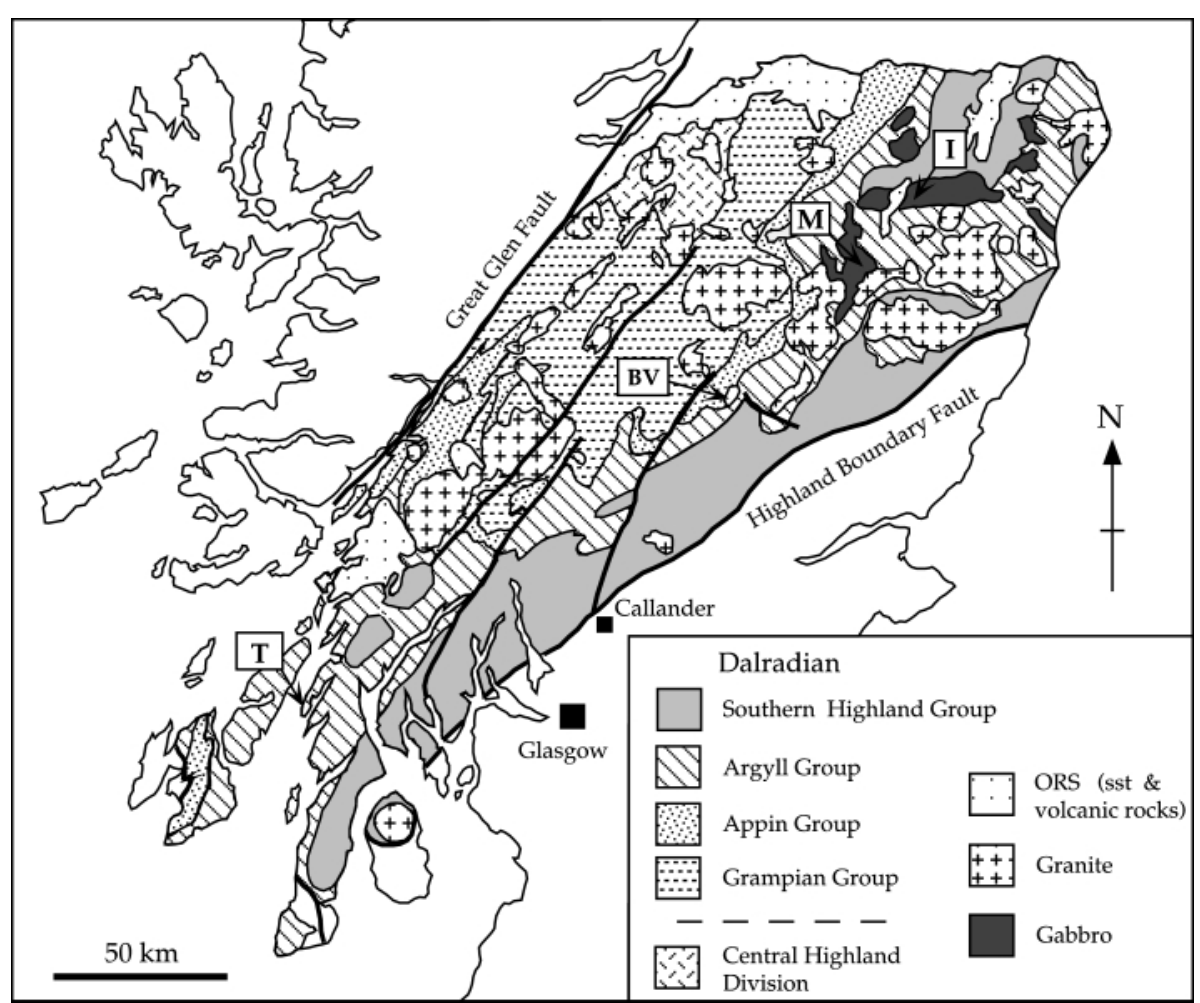

Fig. 1. Map showing the distribution of the main geological units of the Scottish Highlands between the Great Glen and Highland Boundary faults. I, M and T represent sample locations for the Insch Gabbro, Morven Cabrach Gabbro and Tayvallich Tuff respectively. BV represents the Ben Vuirich Granite. the Lower Palaeozoic is also suggested by apparent structural and stratigraphical continuity between Southern Highland Group Dalradian rocks and the Cambrian Leny Limestone from the Callander area (Harris 1962; Tanner 1995) close to the Highland Boundary Fault. These findings do appear to be at-odds with the pre-Ordovician isotopic ages from Southern Highland Group rocks (Harper 1967; Dempster 1985; Dempster et al. 1995), although, as pointed out by Tanner \& Pringle (1999), there are likely to be inherited components to some of the white-mica ages in the low grade rocks at the Highland Border.

In the absence of recognized stratigraphical breaks anywhere within the Highland sequence these data sets and the views generated from them require a re-appraisal of some of the key age constraints on the Dalradian rocks of the Scottish Highlands (see also Prave 1999). We present new U-Pb age data for both the 'Newer Gabbros' of the NE Highlands, whose emplacement is considered to have been close in time to that of peak metamorphism, and for the age of the Tayvallich Volcanics in the SW Highlands, which provides a minimum age for the deposition of the Upper Dalradian sediments.

\section{General geology}

\section{Gabbros of NE Highlands}

The 'Younger basic' or 'Newer Gabbro' rocks (Read 1919) represent a major phase of magma emplaced into the Dalradian metasediments (Fig. 1). They comprise at least six large bodies which range in composition from peridotite cumulates through gabbros and norites to syenites, although the full compositional spectrum is not present in each intrusion. The petrology of the intrusions has been summarized by Wadsworth (1982) and Kneller (1987), and diverse aspects of their geology have been presented in a dedicated volume of the
Scottish Journal of Geology (1970). The intrusions were thought by Stewart \& Johnson (1960) to represent a single sheet folded by the Boyndie syncline, but subsequent reinterpretation of this structure (Treagus \& Roberts 1981) has led to a rejection of this hypothesis. Nonetheless, the various 'Newer Gabbros' are still considered to have been emplaced during a single event (e.g. Ashcroft et al. 1984).

The relationship between the 'Newer Gabbros' and the deformation and metamorphism in the Buchan area has been the subject of several studies (e.g. Fettes 1970; Ashcroft et al. 1984; Ashworth 1985). Although contacts are occasionally complicated by the presence of later shearing (Ashcroft et al. 1984) the gabbros do contact metamorphose the Dalradian Macduff Slates. Porphyroblast-matrix textural relationships indicate that the development of Buchan-style regional metamorphic assemblages was associated with local $\mathrm{D}_{2}$ structures (Treagus \& Roberts 1981). This regional metamorphism predated the emplacement of the gabbros (Fettes 1970; Leslie 1987). Harte \& Hudson (1979), however, suggested that the high- $T$ - low- $P$ Buchan metamorphism could have been produced within the same high heat flow regime which culminated with the intrusion of the gabbros. Dempster et al. (1995) have argued that the kyanite-bearing Barrovian metamorphic assemblages which overprint regional metamorphic andalusitebearing assemblages to the west of the Portsoy-Duchray Hill lineament (Chinner 1980; Treagus \& Roberts 1981; Goodman 1994) could have been caused by magmatic loading producing a pressure increase of up to 2 kbar (Baker 1985; BeddoeStephens 1990). This kyanite growth appears to be associated with the late stages of local $\mathrm{D}_{2}$ (Treagus \& Roberts 1981; Beddoe-Stephens 1990). Hence the final stages of the $D_{2}$ deformation, the Buchan metamorphism, the higher pressure Barrovian overprint, and the crystallization of the gabbros may have been approximately contemporaneous (Fettes 1970). However, the gabbros post-date $\mathrm{D}_{1}$ deformation, and most of 
the $\mathrm{D}_{2}$-related events, which through much of the Highlands are associated with crustal thickening and Barrovian metamorphism (e.g. Fettes et al. 1986; Harte 1988).

\section{Tayvallich Volcanic Formation of SW Highlands}

The 'Tayvallich Volcanics' belong to the Tayvallich Subgroup and form the uppermost part of the Argyll Group of the Dalradian Supergroup. The voluminous basic magmatism, which includes a variety of pyroclastic lithologies, including tuffs and hyaloclastite rocks, pillow lavas and associated sills (Graham 1986), has been linked to the initial stages of Iapetus opening (Anderton 1985) after what is considered by some as a prolonged history of rifting (e.g. Soper et al. 1999; cf. Prave 1999). On the basis of their geochemistry, which is atypical of mid-ocean ridge basalts, other workers have suggested an origin within a transtensional basin (Graham 1986). The succession has experienced both a low temperature, but relatively high-pressure, regional metamorphism (Graham et al. 1983; Skelton et al. 1995) (up to garnet zone) and a phase of earlier hydrothermal metamorphism.

\section{Previous geochronology}

The earliest attempts to date the 'Newer Gabbros' were made by Brown et al. (1965) and Bell (1968) who obtained a variety of $\mathrm{K}-\mathrm{Ar}$ and $\mathrm{Rb}-\mathrm{Sr}$ biotite ages from the intrusions, typically between 444 and $479 \mathrm{Ma}$. (All ages quoted have been recalculated using the decay constants recommended by Steiger \& Jäger (1977).) Pankhurst (1970) determined K-Ar biotite and muscovite ages for the Arnage, Haddo House and Insch intrusions that were relatively uniform, all but one being between 465 and 473 Ma. Pankhurst (1970) also obtained an imprecise Rb-Sr whole-rock age of $492 \pm 26 \mathrm{Ma}$ for the upper zone rocks from the Insch intrusion, this being the most evolved part of the basic bodies and apparently not influenced by crustal contamination. A similar $\mathrm{Rb}-\mathrm{Sr}$ whole-rock age of $489 \pm 23 \mathrm{Ma}$ from schists and gneisses from the thermal aureole of the Haddo House mass was also determined, which Pankhurst (1970) argued represented the age of emplacement of the gabbro. Van Breemen \& Boyd (1972) published a Rb-Sr muscovite-K-feldspar-whole-rock age of $467 \pm 5 \mathrm{Ma}$ from a pegmatite that cuts sheared gabbro at Belhelvie Quarry. Similar late-orogenic gabbros are emplaced into Dalradian metasediments of western Ireland (Tanner 1990); these share a broadly similar history to the gabbros of NE Scotland. The Irish gabbros have recently been dated by high precision $\mathrm{U}-\mathrm{Pb}$ determinations on zircon and yield ages of c. 470 and $475 \mathrm{Ma}$ (Friedrich et al. 1999a).

The Tayvallich Volcanics were dated by Halliday et al. (1989), who analysed a felsic 'keratophyre' from the Tayvallich Peninsula and obtained a conventional multi-grain U-Pb zircon age of $595 \pm 4 \mathrm{Ma}$, the date defining a simple discordia line. Although the keratophyre was interpreted by these authors as dating the volcanic succession, the field description given by Gower (1977) suggested an intrusive cross-cutting relationship with adjacent rocks, and hence there is some uncertainty about its relationship to the Dalradian sequence. An examination of the zircon separate used in the study of Halliday et al. (1989) using both cathodoluminescence and back-scattered electron imaging revealed that many of the individual grains contain evidence of cores which were

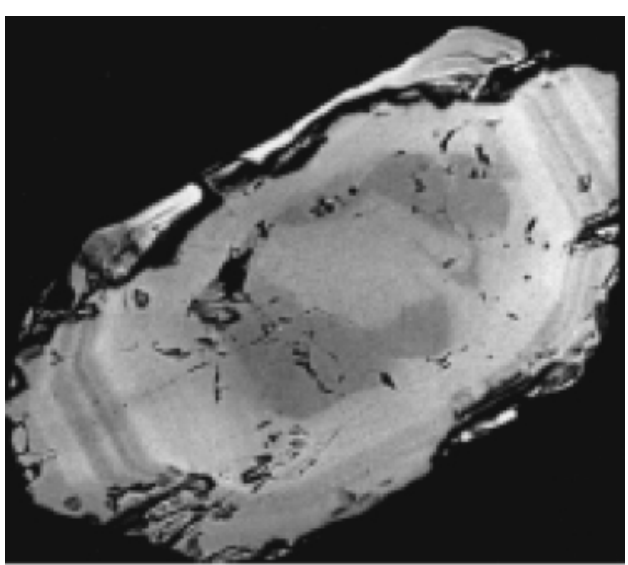

Fig. 2. Back-scattered electron image of zircon from keratophyre dated by Halliday et al. (1989). Field of view $150 \mu \mathrm{m}$.

surrounded by euhedral magmatic growth zones (Fig. 2). This may point to an inherited component within the $595 \pm 4 \mathrm{Ma}$ age of Halliday et al. (1989).

Given the importance of reliable ages from the Dalradian metasediments, both the 'Newer Gabbros' and the Tayvallich Volcanics were targeted for further geochronological investigation.

\section{Analytical techniques}

Zircons were separated using a jaw crusher, disc grinder and Wilfley Table, followed by heavy liquids and a Frantz LB-1 magnetic separator.

The zircons from the 'Newer Gabbros' were analysed by thermal ionization mass spectrometry at SUERC. The zircons were subdivided on the basis of magnetic susceptibility and grain size. Analysed fractions were handpicked under alcohol, abraded (Krogh 1982), and then washed sequentially in hot $3 \mathrm{M} \mathrm{HNO}_{3}$, distilled water and distilled acetone. They were weighed into Savillex ${ }^{\circledR}$ PFA microcapsules (Parrish 1987) along with a mixed ${ }^{205} \mathrm{~Pb}^{235} \mathrm{U}$ spike (Parrish \& Krogh 1987) and $0.15 \mathrm{ml} \mathrm{48 \%} \mathrm{HF}$ and $0.015 \mathrm{ml} 7 \mathrm{M} \mathrm{HNO}_{3}$. The microcapsules were placed in a steel-jacketed, $125 \mathrm{ml}$ PTFE Parr ${ }^{\circledR}$ bomb to which $6 \mathrm{ml} \mathrm{48 \%} \mathrm{HF} \mathrm{were} \mathrm{added.} \mathrm{The} \mathrm{bomb} \mathrm{was} \mathrm{heated} \mathrm{in} \mathrm{an} \mathrm{oven} \mathrm{for}$ c. $30-48$ hours at $240{ }^{\circ} \mathrm{C}$, and then the solution in the microcapsules was evaporated. To ensure dissolution of the resultant fluoride salts, $0.2 \mathrm{ml} \mathrm{3.1} \mathrm{M} \mathrm{HCl}$ were added to the samples; they were put back into the $\operatorname{Parr}^{\mathbb{B}}$ bomb containing $5 \mathrm{ml} 3.1 \mathrm{M} \mathrm{HCl}$, and reheated in an oven at $210{ }^{\circ} \mathrm{C}$ for $c$. 14 hours. Separation and purification of $\mathrm{U}$ and $\mathrm{Pb}$ followed the method of Krogh (1973). Pb and U were loaded separately on single Re filaments using $\mathrm{H}_{3} \mathrm{PO}_{4}$ and silica gel. Analyses were performed on a VG Sector 54-30 thermal ionization mass spectrometer. The analytical data reported here were collected using an ion-counting Daly detector. All $\mathrm{Pb}$ analyses were performed at $1340 \pm 30{ }^{\circ} \mathrm{C}$ and $\mathrm{U}$ at $1670 \pm 30^{\circ} \mathrm{C}$ in order to minimize intersample mass fractionation. Ratios were corrected for $\mathrm{Pb}$ mass fractionation of $0.086 \pm 0.051 \% \mathrm{amu}^{-1}$, and $\mathrm{U}$ mass fractionation of $0.102 \pm 0.047 \% \mathrm{amu}^{-1}$ based on multiple analyses of NBS981 and U500. Data reduction, error propagation and plotting were performed using the ISOPLOT and PBDAT programs (Ludwig 1993a,b). Ages were calculated using the decay constants of Jaffey et al. (1971). All errors are quoted at the $2 \sigma$ level. Analytical data are presented in Table 1. The zircons from the Tayvallich Volcanics were analysed on the SHRIMP RG at the Stanford University-USGS microisotopic analytical centre (SUMAC). Procedures followed standard SHRIMP operating conditions (Muir et al. 1996). A $7 \mathrm{nA}$ primary $\mathrm{O}_{2}$-beam was used to erode a pit of $30 \mu \mathrm{m}$ diameter with positive secondary ions extracted. Individual masses were analysed at a mass resolution of $7000 \mathrm{R}(10 \%$ full-width base height definition). $\mathrm{U}$ and $\mathrm{Th}$ 
T. J. DEMPSTER ET $A L$

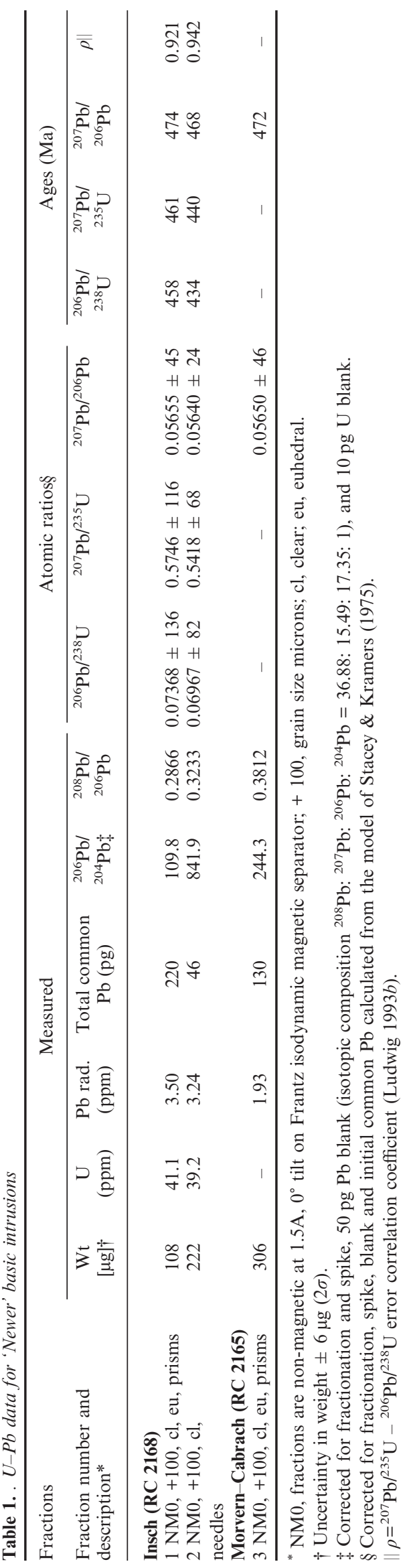


Table 2. $U-P b$ isotope data for zircons from the Tayvallich tuffs

\begin{tabular}{|c|c|c|c|c|c|c|c|c|}
\hline & $\mathrm{U}(\mathrm{ppm})$ & Th (ppm) & $\mathrm{Th} / \mathrm{U}$ & f206 (\%) & $\begin{array}{c}{ }^{204} \mathrm{~Pb} /{ }^{206} \mathrm{~Pb} \\
\left(\times 10^{-5}\right)\end{array}$ & ${ }^{207} \mathrm{~Pb} /{ }^{206} \mathrm{~Pb}$ & ${ }^{238} \mathrm{U} /{ }^{206} \mathrm{~Pb}$ & Age (Ma) \\
\hline 1.1 & 201 & 209 & 1.040 & $-0.04 \pm 0.10$ & $6 \pm 8$ & $0.0593 \pm 0.0008$ & $10.43 \pm 0.16$ & $590.5 \pm 8.6$ \\
\hline 3.1 & 1263 & 971 & 0.769 & $0.10 \pm 0.05$ & $5 \pm 2$ & $0.0608 \pm 0.0004$ & $10.19 \pm 0.07$ & $602.7 \pm 4.1$ \\
\hline 4.1 & 194 & 155 & 0.800 & $0.10 \pm 0.15$ & $5 \pm 12$ & $0.0607 \pm 0.0012$ & $10.25 \pm 0.13$ & $599.5 \pm 7.3$ \\
\hline 5.1 & 119 & 73 & 0.614 & $0.23 \pm 0.21$ & $17 \pm 13$ & $0.0613 \pm 0.0017$ & $10.57 \pm 0.19$ & $581.5 \pm 9.9$ \\
\hline 6.1 & 1192 & 845 & 0.709 & $0.00 \pm 0.04$ & $1 \pm 1$ & $0.0600 \pm 0.0003$ & $10.22 \pm 0.07$ & $601.7 \pm 3.8$ \\
\hline 7.1 & 694 & 572 & 0.824 & $0.04 \pm 0.06$ & $1 \pm 2$ & $0.0603 \pm 0.0005$ & $10.21 \pm 0.08$ & $602.2 \pm 4.4$ \\
\hline 8.1 & 2742 & 3964 & 1.445 & $-0.07 \pm 0.04$ & $0 \pm 1$ & $0.0598 \pm 0.0003$ & $9.92 \pm 0.06$ & $619.4 \pm 3.5$ \\
\hline 9.1 & 228 & 178 & 0.781 & $0.06 \pm 0.13$ & $11 \pm 8$ & $0.0607 \pm 0.0010$ & $10.07 \pm 0.10$ & $610.2 \pm 6.0$ \\
\hline 10.1 & 397 & 297 & 0.748 & $0.02 \pm 0.07$ & $1 \pm 4$ & $0.0601 \pm 0.0006$ & $10.22 \pm 0.08$ & $601.9 \pm 4.8$ \\
\hline 11.1 & 492 & 478 & 0.972 & $0.02 \pm 0.07$ & $0 \pm 3$ & $0.0600 \pm 0.0006$ & $10.30 \pm 0.08$ & $597.1 \pm 4.6$ \\
\hline 12.1 & 1256 & 930 & 0.741 & $-0.07 \pm 0.06$ & $1 \pm 2$ & $0.0594 \pm 0.0005$ & $10.24 \pm 0.07$ & $601.0 \pm 3.8$ \\
\hline 13.1 & 1345 & 1007 & 0.749 & $0.01 \pm 0.06$ & $0 \pm 2$ & $0.0601 \pm 0.0005$ & $10.18 \pm 0.07$ & $603.8 \pm 3.7$ \\
\hline 14.1 & 1270 & 918 & 0.723 & $0.02 \pm 0.06$ & $3 \pm 1$ & $0.0602 \pm 0.0005$ & $10.18 \pm 0.08$ & $604.1 \pm 4.4$ \\
\hline
\end{tabular}

Errors are $1 \sigma . \mathrm{U} / \mathrm{Pb}$ normalized to $1099 \mathrm{Ma}$ AS57 standard. Ten samples give $1099.4 \pm 2.4(1 \sigma)$ with MSWD $=0.63(0.5 \%$ uncertainty summed in quadrature for standard and unknown analyses). Comments: Analysis 8.1 is a high U grain. Older apparent age may be due to inappropriate calibration for high $\mathrm{U}$ grains. All remaining analyses give a satisfactory mean $601.4 \pm 1.3 \mathrm{Ma}(1 \sigma)$. Summing in the final error of the standard gives $601.4 \pm 3.7 \mathrm{Ma}\left(2 \sigma_{\mathrm{m}}\right)$ or $601 \pm 4 \mathrm{Ma}$

concentrations were normalized to the Australian National University standard SL13 (238 ppm U; 21 ppm Th). Pb/U ratios were calibrated with UO/U and normalized to AS57 from the $1099 \mathrm{Ma}$ Duluth Anorthosite Complex. Analytical data are presented in Table 2. Ten standards were analysed during the course of the analytical session and all were within error to give a mean ${ }^{206} \mathrm{~Pb} /{ }^{238} \mathrm{U}$ ratio of $1099 \pm 2.4 \mathrm{Ma}$ $\left(1 \sigma_{\mathrm{m}}, \mathrm{MSWD}=0.63\right)$; equating to a relative uncertainty of $0.5 \%$ to be added as a systematic error to the normalized age determination.

\section{Sampling, zircon morphology and results \\ Insch}

A sample (RC 2168) of an upper zone 'b' syenogabbro of the Insch intrusion (Wadsworth 1970) from the disused quarry near Mill of Johnston [Grid Reference NJ 571 247] yielded a zircon population of needles, euhedral prisms and subrounded grains. The sample is a medium-grained, clinopyroxene-orthopyroxene monzonite with minor marginal amphibolitization of the mafic minerals. Orthoclase is more abundant than plagioclase feldspar. Apatite, zircon and opaques are common accessory phases. Typically the zircons display no zoning when examined using back-scattered electron images and only weak oscillatory and sector zoning under cathodoluminescence. Non-magnetic, clear, crack- and inclusion-free needle and prism fractions were picked and strongly abraded. The prisms (fraction \#1) are slightly discordant $(3.4 \%)$ with a ${ }^{207} \mathrm{~Pb} /{ }^{206} \mathrm{~Pb}$ age of $474 \mathrm{Ma}$; the needles are a little more discordant with a ${ }^{207} \mathrm{~Pb} /{ }^{206} \mathrm{~Pb}$ age of $468 \mathrm{Ma}$ (Table 1, Fig. 3). The U contents of both fractions are extremely low at c. $40 \mathrm{ppm}$, comparable with those of some granulite facies gneisses (e.g. Corfu et al. 1994). Regression of the data with a fixed lower intercept of $0 \pm 50$ Ma (Dunning \& Krogh 1985) yields an age of $470 \pm 9 \mathrm{Ma}$ that is considered to be the crystallization age of the Insch gabbro.

\section{Morven Cabrach}

Zircons from a sample (RC 2165) of medium-grained clinopyroxene-bearing monzonite from Craig of Bunzeach within the Morven Cabrach intrusion [NJ 370 094] contain ubiquitous inclusions of apatite and opaque oxides. Orthoclase

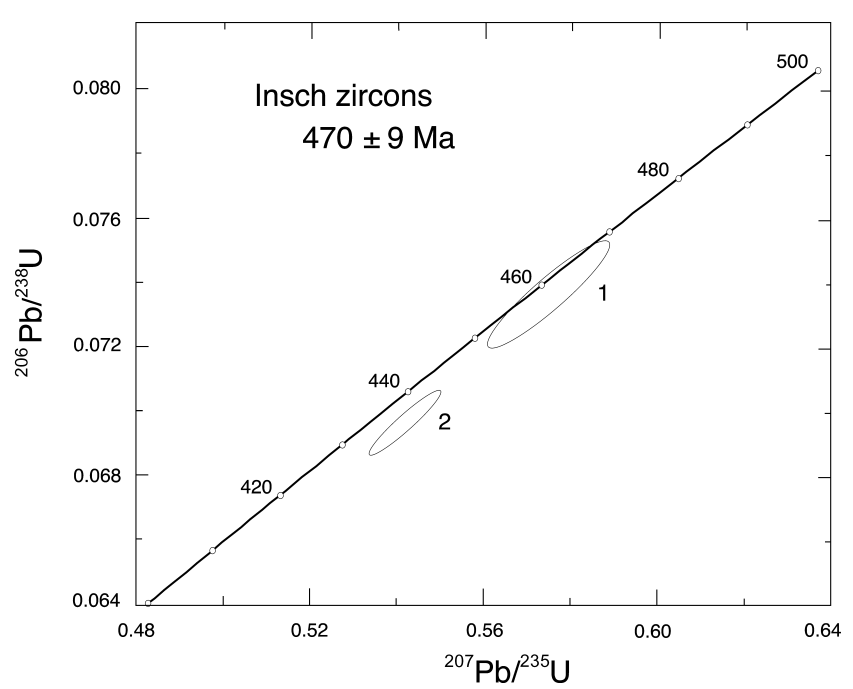

Fig. 3. $\mathrm{U}-\mathrm{Pb}$ concordia plot showing analyses of zircons from the Insch gabbro (1, prisms; 2, needles).

is somewhat less abundant in this sample than in the monzonite from Insch, coarse biotite is present and amphibolitization of pyroxene and biotite is pervasive with only rare relicts of clinopyroxene preserved. Occasional small euhedral cores are recognized within a few of the zircon prisms (Fig. 4) which contain concentric oscillatory zoning parallel to the outer edges of the grains. These cores probably represent an earlier phase of magmatic growth. However typically the zircons are unzoned. A needle fraction contained about half of the radiogenic $\mathrm{Pb}$ of the Insch samples, and yielded a ${ }^{207} \mathrm{~Pb} /{ }^{206} \mathrm{~Pb}$ age of $472 \mathrm{Ma}$ (Table 1), similar to the age obtained from Insch. The low concentration of radiogenic $\mathrm{Pb}$ implies that there is only about half the $\mathrm{U}$ content of the zircons at Insch, assuming that the intrusions are the same age. Because of such low $U$ contents we were unable to analyse successfully the U content of these needles. Nonetheless, the similarity of the ${ }^{207} \mathrm{~Pb} /{ }^{206} \mathrm{~Pb}$ ages, coupled with the needle morphology, lead us to conclude that the Morven Cabrach intrusion is also the same age (c. $470 \mathrm{Ma}$ ) as Insch. 


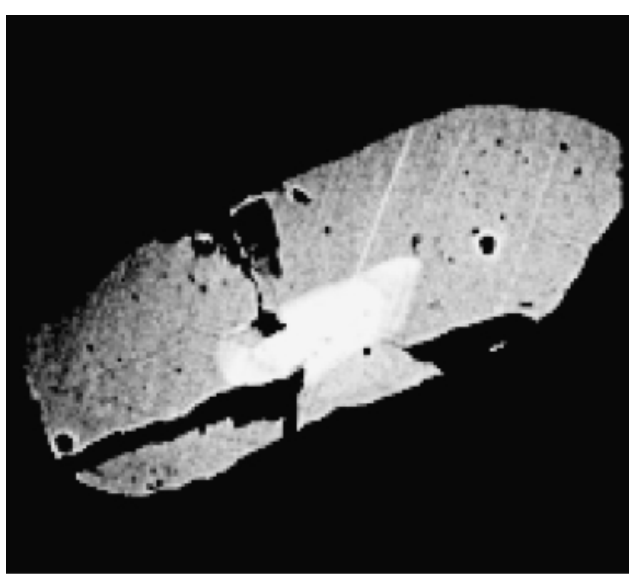

Fig. 4. Back-scattered electron image of zircon separated from the Morven Cabrach gabbro. Field of view $150 \mu \mathrm{m}$.

\section{Tayvallich Volcanics}

A sample of tuff was collected from the western coast of the Tayvallich Peninsula at Port a' Bhuailteir [NR 688 810). Here a series of felsic tuff bands are interstratified with typical dark green fine-grained mafic tuffs and breccias contained within the more massive pillowed and non-pillowed mafic lava sequences (Gower 1977). The thickest of these felsic tuff bands was sampled; it forms a narrow $(c .0 .4 \mathrm{~m})$ pale pink band interbedded within the main lava sequence which consists of stratified dark green amphibolites. This tuff band can be traced along strike parallel to the coast for $c .60 \mathrm{~m}$. Within this sequence, coarse breccias occur that contain large clasts of 'keratophyre', similar in hand specimen to the intrusion dated by Halliday et al. (1989). The tuff is composed predominantly of fine-grained (c. $25 \mu \mathrm{m})$ quartz and albite, with small white micas defining a penetrative cleavage, rare biotite and calcite, and opaques. Locally the band contains coarser-grained $(1 \mathrm{~mm})$ white feldspars. Zircon separates were examined for signs of inheritance using a combination of back-scattered electron imaging, and cathodoluminescence and unlike those from the Halliday et al. (1989) study, the zircons contain no obvious cores. Zircons from the Tayvallich volcanics show a wide range in trace element chemistry with $U$ variation from 120 to $2700 \mathrm{ppm}$, and Th from 73 to $4000 \mathrm{ppm}$, and Th/U ranging from 0.59 to 1.45 . Analyses show very low levels of common $\mathrm{Pb}$ with estimations based on ${ }^{204} \mathrm{~Pb}$ being within error of zero. This is also apparent on the conventional Tera-Wasserburg concordia diagram (uncorrected common $\mathrm{Pb}$ plotted) with all data plotting within error of the concordia (Fig. 5). Thirteen of the fourteen zircon analyses lie within error of their mean ${ }^{206} \mathrm{~Pb} /{ }^{238} \mathrm{U}$ age of $601.4 \pm 1.3 \mathrm{Ma}\left(1 \sigma_{\mathrm{m}}\right.$, MSWD $=0.82$ ). One analysis lies to the older side of the main cluster. It may be xenocrystic, but this grain has extremely high $\mathrm{U}$ and Th concentrations and it is more likely that this is an artifact of the $\mathrm{U}-\mathrm{Pb}$ calibration procedure. The zircons from this rock therefore appear to show only a single population with a calculated age of $601 \pm 4 \mathrm{Ma}\left(2 \sigma_{\mathrm{m}}\right)$ that is within error of the age determined by Halliday et al. (1989). This date confirms a late Precambrian age for the start of Southern Highland Group deposition. The 'inherited' cores of zircon identified within the 'keratophyre' seem likely to represent an early magmatic pulse within the same igneous system.

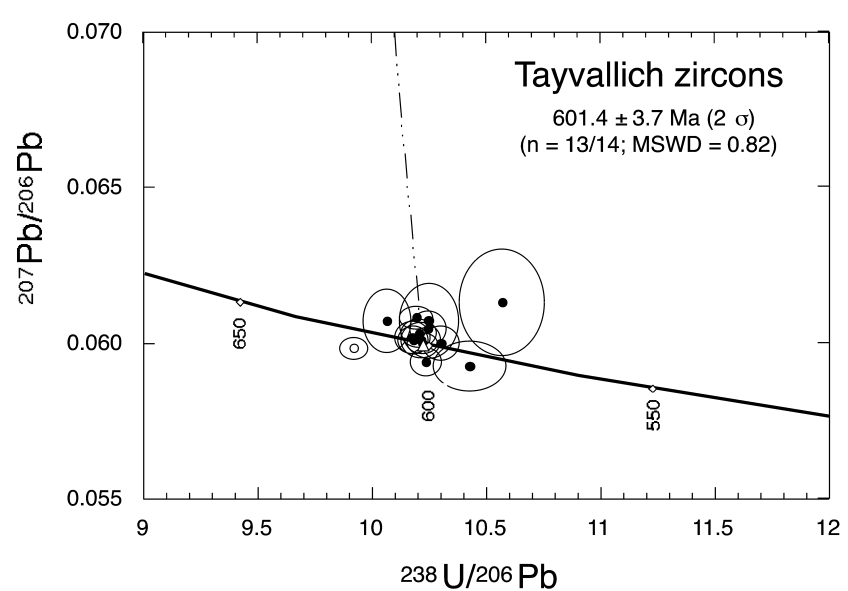

Fig. 5. Tera-Wasserburg concordia plot showing U-Pb SHRIMP analyses of the zircons from the Tayvallich Tuff.

Implications for the age of orogenesis and deposition of the Dalradian rocks.

\section{Stratigraphical continuity at the top of the Dalradian pile and the timing of Palaeozoic orogenesis}

Deposition of all of the Dalradian sediments, nappe formation, thickening and the early parts of the regional metamorphic history, must have occurred before $470 \pm 9 \mathrm{Ma}$, the age of the 'Newer gabbros' (Fettes 1970). This situation appears to be strikingly similar to that reported by Friedrich et al. (1999a, b) who obtained ages of $c \cdot 470-475 \mathrm{Ma}$ for the gabbros, emplaced in previously metamorphosed Dalradian rocks (Yardley et al. 1987; Tanner 1990) from Connemara, Ireland. Friedrich et al. (1999a, b) concluded that the syn- $\mathrm{D}_{2}$ intrusion of these gabbros (Wellings 1998) at $c .475 \mathrm{Ma}$ coincided with the end of sedimentation on the Laurentian passive margin (which was interpreted to include the Dalradian sediments) and hence dates the onset of the Grampian orogeny. On this basis they concluded that the Grampian orogeny was very short-lived. Although a tempting correlation to make (Dewey \& Mange 1999), this assumes a close proximity at this time between Laurentia and the Dalradian blocks that may not be justified (e.g. Bluck et al. 1997), and a more cautious approach may be warranted.

The 'Newer Gabbro' U-Pb zircon ages, in combination with mica cooling ages from much of the Highlands (Dewey \& Pankhurst 1970; Dempster 1985) do point to a fairly rapid end to the Caledonian orogeny, especially within the southern parts of the belt. The age of peak Barrovian metamorphic garnet growth in the Scottish Dalradian, $467 \pm 3 \mathrm{Ma}$ (Oliver et al. 2000) is very similar to that of the gabbros. However, there are few age constraints on the start of orogenesis. Heating associated with thickening-related metamorphism of the sort preceding the gabbro emplacement is typically slow (England \& Richardson 1977), much slower than thermal changes driven by rapid unroofing (e.g. Baldwin et al. 1993; Crowhurst et al. 1996). Hence the $470 \pm 9 \mathrm{Ma}$ age of the late orogenic Scottish gabbros is difficult to reconcile with both continued Dalradian deposition into the Tremadoc/Arenig (Tanner 1995, Molyneux 1998), and an entirely post-Arenig (<c. $466 \mathrm{Ma}$; Tucker \& McKerrow 1995) orogeny (Soper et al. 1999). Therefore the crustal thickening that affects the Southern Highland Group rocks (deposited post-600 Ma) 
most likely represents a pre-Arenig Caledonian event (Dempster et al. 1995).

If deposition of the Southern Highland Group did indeed continue into the Ordovician (Soper et al. 1999), then not only is rapid prograde metamorphism required but also exceptionally slow deposition is needed. In this model, typically about 2-3 km of Southern Highland Group sediments (Harris et al. 1994) must have accumulated in $c$. $130 \mathrm{Ma}$ (i.e. roughly equivalent to the total Ordovician-Devonian time span). However, thickly bedded turbidite successions are not typical of slow deposition! Continuous deposition within the Highland Border Complex also appears to be ruled out by the presence of ophiolitic units such as the amphibolite-facies metabasic rocks of the ophiolite sole (Henderson \& Robertson 1982; Dempster \& Bluck 1991), found adjacent to the low-grade greenschist-facies Dalradian rocks. This juxtaposition, the presence of exotic clasts in boulder-bearing conglomerates (Dempster \& Bluck 1989), and the thick mylonite, found locally in the Highland Border Complex (Henderson \& Robertson 1982), is incompatible with models of continuous deposition at the southern margin of the Dalradian. Such evidence of a faulted (terrane) boundary with considerable displacement along the edge of the Highlands suggests that models relying on compatible geological histories across the fault-bounded blocks of Scotland face problems.

We conclude that continuous deposition for $130 \mathrm{Ma}$ is unlikely to have occurred, and there must be breaks and omissions from the sequence between the reliably dated Arenig (c. $470 \mathrm{Ma}$ ) rocks (Curry et al. 1984) at the Highland Border and the reliably dated late Precambrian (Tayvallich) $600 \mathrm{Ma}$ Dalradian rocks. With respect to the Ordovician Highland Border Complex rocks, apparent structural continuity (Johnson \& Harris 1967) within a complex fault zone is an unreliable indicator of stratigraphical continuity (Tobisch \& Fiske 1982; Tavarnelli \& Holdsworth 1999).

\section{Stratigraphical continuity in the middle of the Dalradian pile}

Whilst it is difficult to understand how a Barrovian metamorphism could have been generated in the Dalradian rocks during a short-lived Arenig orogeny, it is especially difficult to see how two separate regional metamorphic events (e.g. Dempster \& Harte 1986) could be squeezed into the same time gap between proposed Arenig (c. $470 \mathrm{Ma}$ ) deposition of the uppermost Dalradian and the regional cooling event at c. $460 \mathrm{Ma}$. Although distinguishing separate regional metamorphic events from stages in a single prograde cycle is difficult, prograde Barrovian metamorphism is not typically associated with increasing pressures as found in areas of the Dalradian (Dempster \& Harte 1986). Given the relatively rapid end to the $470 \mathrm{Ma}$ event (e.g. Dempster 1985) the presence of polymetamorphic assemblages suggest that the earliest phase of regional metamorphism significantly predates a widespread c. $470 \mathrm{Ma}$ overprint (Oliver et al. 2000). Such evidence of an early metamorphism is mostly restricted to the Argyll Group rocks and apparently 'deeper' stratigraphic levels (Chinner \& Heseltine 1979; Beddoe-Stephens 1990; Dempster \& Harte 1986). In addition, rare pre- $470 \mathrm{Ma}$ isotopic dates are found within the older parts of the Dalradian pile (e.g. Argyll Group, Dempster 1985; Dempster et al. 1995) and the Central Highlands area (Noble et al. 1996; Highton et al. 1999). Although the timing of an early event is reasonably well known as Neoproterozoic in the Central Highlands area (Noble et al. 1996; Highton et al. 1999), its nature, timing or even presence, is not well constrained in the Argyll and Appin Group rocks. The emplacement of the Ben Vuirich Granite at $590 \pm 2 \mathrm{Ma}$ (Rogers et al. 1989) does provide some indications of the thermal state of these rocks during the Late Proterozoic. The structural age of this intrusion depends on correlations of structures from the southern boundary of the Highlands and has been the subject of many publications (Bradbury et al. 1976; Rogers et al. 1989; Tanner \& Leslie 1994; Tanner 1996). Structural arguments in favour of either pre- $\mathrm{D}_{1}$ or post- $\mathrm{D}_{1}$ emplacement, and on the nature of pre-hornfels fabric, are presented elsewhere (Tanner 1996), however, the interpretation of these relationships is such a key factor that a few aspects that are independent of structural considerations are highlighted below.

(1) High- and moderate-temperature metamorphic aureoles around granites are not typically developed in rocks that have not previously experienced regional metamorphism (see Kerrick 1991).

(2) The Ben Vuirich Granite was emplaced into crust that locally preserves evidence of an 'early' phase of regional metamorphism (Dempster \& Harte 1986).

(3) Pressures within the aureole defined on the basis of the reported contact metamorphic assemblages indicate conditions of between 2 and 4 kbar (Tanner 1996).

The pressures of the contact metamorphic rocks have perhaps the most significant implications for the timing of the intrusion relative to the tectonothermal evolution of the Dalradian. These pressure estimates have been revised by Ahmed-Said \& Tanner (2000) on the basis of the composition of the granite. However, their revised lower pressure estimate of $\leq 2 \mathrm{kbar}$ fails to incorporate the effects of the anorthite component in plagioclase on melt composition (see Thompson 1981; Johannes 1984), a factor, which if ignored, will significantly underestimate pressures. On an $\mathrm{Ab}-\mathrm{Or}-\mathrm{Qz}$ phase diagram the position of the granite minimum is shifted directly away from albite, by the effects of both low pressure and increased $\mathrm{Ca}$ in plagioclase (James \& Hamilton 1969). The contact metamorphic assemblages of andalusite-cordieritebiotite-muscovite-quartz (Tanner 1996; Ahmed-Said \& Tanner 2000) are compatible with peak temperatures in the range $550-600{ }^{\circ} \mathrm{C}$ (Pattison \& Tracy 1991). This estimate used in combination with the temperature estimate of the granite magma of $\leq 700{ }^{\circ} \mathrm{C}$ (Ahmed-Said \& Tanner 2000) suggests that original country rock temperatures may have been of the order of $400-500{ }^{\circ} \mathrm{C}$ (Jaeger 1968) (i.e. well into greenschistfacies conditions at the time of emplacement). Even assuming an unrealistically high geothermal gradient (cf. Ahmed-Said \& Tanner 2000) a minimum depth of emplacement of $8-10 \mathrm{~km}$ is required.

Tanner's (1996) pressure estimate, based on the equilibrium cordierite-andalusite-muscovite-biotite-quartz assemblage (see Pattison \& Tracy 1991) in the aureole, yields a similar depth of emplacement for the $590 \mathrm{Ma}$ granite of at least $7 \mathrm{~km}$ and up to $14 \mathrm{~km}$. Recent work has suggested that the granite was emplaced into the relatively thin sequence of strata of the upper part of the Appin Group (A. G. Leslie pers. comm. but see Bradbury et al. 1979). Quoting a maximum thickness of $9 \mathrm{~km}$ for the whole of the Argyll Group determined in Harris et al. (1994), Tanner (1996) suggested this would be consistent with pre-tectonic emplacement of the granite. However, crucially the maximum sedimentary thickness takes no account of tectonic thickening or lateral sedimentary thickness 
variations (Harris et al. 1994). It is notable that the similarly derived estimate of $>25 \mathrm{~km}$ for thickness for the whole Dalradian sedimentary pile, is greater than the thickest passive margin sequence (Miall 1990), or indeed any sedimentary thickness in present day basin settings. This would place the base of the Dalradian basin within a few kilometres of the base of the continental crust! Even the estimated $9 \mathrm{~km}$ for the Argyll Group alone is well in excess of maximum basin thickness in most tectonic settings. Where the post-deformational thicknesses of the Argyll Group rocks are constrained close to the Central Perthshire area (Harris et al. 1994, fig. 14, S8-10), values of $c$. 3-5 km are reported. Such thicknesses are not only far more realistic but crucially would be inadequate to generate the pressures of metamorphism experienced in the aureole rocks of the Ben Vuirich Granite, even allowing for large errors in geobarometry.

The possibility that these rocks were thickened during the $870-780 \mathrm{Ma}$ orogeny that affected Moine and Central Highland Division rocks to the north can not be entirely discounted. However, the presence of glacial deposits at deeper levels within the apparent stratigraphy argues for a thickening event between 720 and $590 \mathrm{Ma}$ ago (see next section).

Consequently we conclude that an orogenic break may be present in the middle of the Dalradian succession somewhere stratigraphically above the Appin Group and below the Tayvallich Volcanics.

\section{Global events and Dalradian stratigraphy.}

The late Proterozoic Dalradian rocks of Scotland and Ireland appear to contain abundant evidence of glacial activity, notably the Port Askaig Boulder Bed, which occurs at the base of the Argyll Group (Spencer 1971). This is not surprising given that Late Proterozoic glacial deposits are known throughout the globe (Hambrey 1983; Kaufman et al. 1997; Shields 1999; Evans 2000). Their presence at low- and mid-palaeolatitudes, together with associated excursions in the carbon isotope signature, has led to recent speculation of the existence of a Precambrian 'snowball' Earth (Hoffman et al. 1998). Glacial activity is recognized within two main pulses at c. $720 \mathrm{Ma}$ (Sturtian) and $580 \mathrm{Ma}$ (Marinoan) (e.g. Brasier et al. 2000) although there may be multiple events within each pulse (Kennedy et al. 1998).

The confirmation of a $600 \mathrm{Ma}$ age for the Tayvallich Volcanics and the characteristic signature of diamictites and carbonates seen with some of the tillites (e.g. Port Askaig Boulder Bed) places further constraints on the stratigraphy of the Dalradian (e.g. Prave 1999; Brasier \& Shields 2000). The apparently close stratigraphical association of the Tayvallich Volcanics with the Loch na Cille Boulder Bed (Elles 1935) suggests that if this is a tillite, it is probably the product of Marinoan glacial activity (Condon \& Prave 2000). The occurrence of at least two other tillites apparently at stratigraphic levels significantly below the $600 \mathrm{Ma}$ Tayvallich Volcanics suggests that these are most likely to be associated with the Sturtian event (c. $720 \mathrm{Ma}$ ). In this regard the Kinlochlaggan Boulder Bed (Treagus 1997) and the Port Askaig Boulder Bed may represent different pulses of this event, albeit apparently separated by significant stratigraphic thickness, or alternatively they may represent the same Sturtian (or a later) glacial horizon duplicated tectonically (see Evans \& Tanner 1996; Treagus 1997; Evans \& Tanner 1997; Robertson \& Smith 1999).
We conclude that either significant parts of the Dalradian stratigraphy (and the possible faunas in some of these sediments (Brasier \& McIlroy 1998, but see Brasier \& Shields 2000)) are of Sturtian age (c. $720 \mathrm{Ma})$, or major tectonic breaks occur within the Dalradian stratigraphy to allow the Port Askaig Boulder Bed to be linked to the Marinoan event. However, if a Sturtian age for the Port Askaig Boulder Bed, and a model involving continuous Dalradian sedimentation to Arenig time, are both accepted then the Argyll and Southern Highland group sediments alone represent a highly improbable $250 \mathrm{Ma}$ of uninterrupted deposition (Fig. 6). An alternative model (Fig. 6) is clearly more realistic and involves one or more orogenic breaks within the Dalradian stratigraphy.

\section{Implications of a broken stratigraphy}

Some of the implications of the presence of orogenic breaks, separating smaller packages of rock, within the 'Dalradian' are as follows.

(1) Stratigraphic continuity within the Dalradian block (cf. Harris \& Pitcher 1975; Anderton 1985; Harris et al. 1994) would be destroyed. Models of Dalradian history built on this basis, such as the evolution from extensional basins to passive margin drape (e.g. Anderton 1985) would also be rejected.

(2) A corollary of this is that the Dalradian Supergroup is not an ideal sequence to use for constructing a Neoproterozoic chemostratigraphy (cf. Brasier \& Shields 2000).

(3) The unified structural interpretation of the Dalradian block would no longer be tenable as there can not be complete structural continuity between the units. Generations of structural geologists have correlated structures from Southern Highland Group to Appin Group rocks and even from the Central Highland Division (with reliable metamorphic ages of $800 \mathrm{Ma}$, e.g. Noble et al. 1996) all the way through to the undisputed Ordovician rocks (Curry et al. 1982) at the Highland Border. Thus, throughout this crustal block, structures seem to follow a consistent sequence of deformation phases with consistent orientations and fabrics (Harris et al. 1976; Harte et al. 1984; Lindsay et al. 1989). Although the progressive evolution of styles may simply be a function of changing rheology, consistent orientations may be difficult to produce during a sequence of unrelated orogenic events (but see Tavarnelli \& Holdsworth 1999).

(4) The way would be open for models that involve tectonic duplication and disruption of the overall chronostratigraphy. For example, rock units from the traditional stratigraphy could conceivably represent crustal terranes of identical age. Until reliable geochronological constraints are available for the rocks of the existing Argyll, Appin and Grampian groups, models involving significant repetitions within the sequence are plausible.

(5) The metamorphism of the Scottish Highlands would be seen as representing a variable Ordovician overprint on blocks with disparate thermal and tectonic histories.

Models invoking Precambrian orogenesis through much of the Dalradian pile are faced with the enormous problem that they require the presence of an orogenic break which has proved to be very elusive. Despite the recognition of some discontinuities (Gregory 1931; Garson \& Plant 1973; Fettes et al. 1991; Goodman 1994; Robertson \& Smith 1999), including possible periods of local non-deposition, the absence of obvious orogenic unconformities makes models invoking Late Precambrian, Cambrian and Early Ordovician crustal 

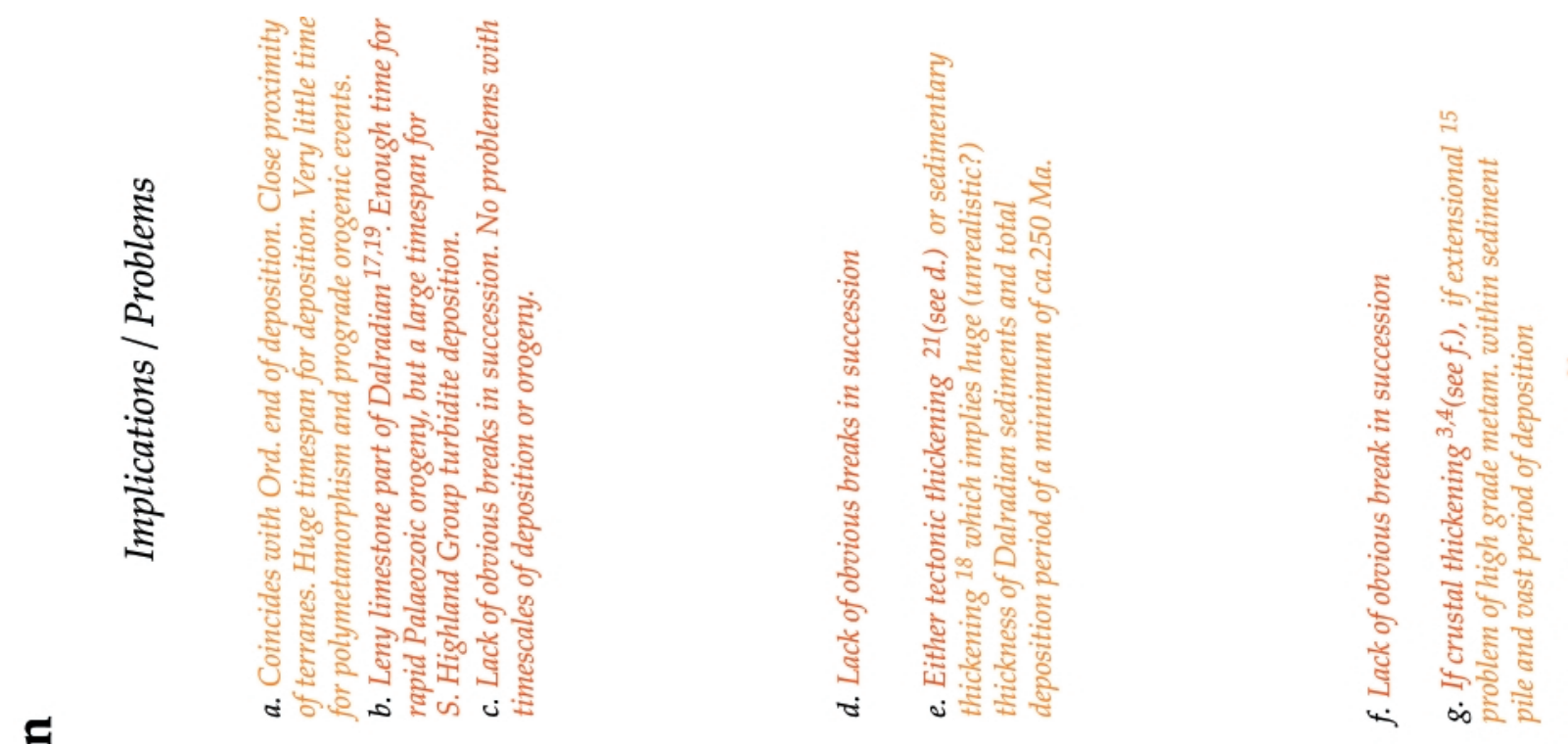

: $: \frac{3}{8}$

苟
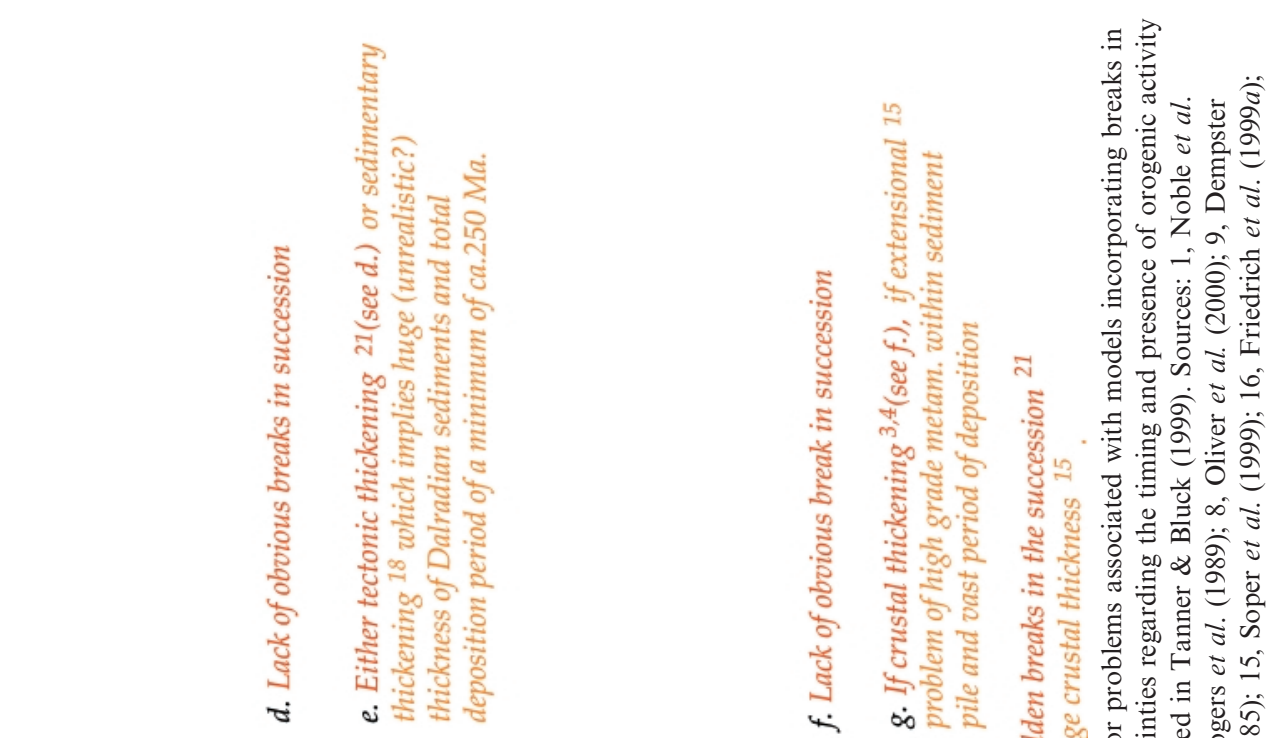

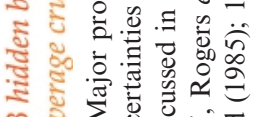
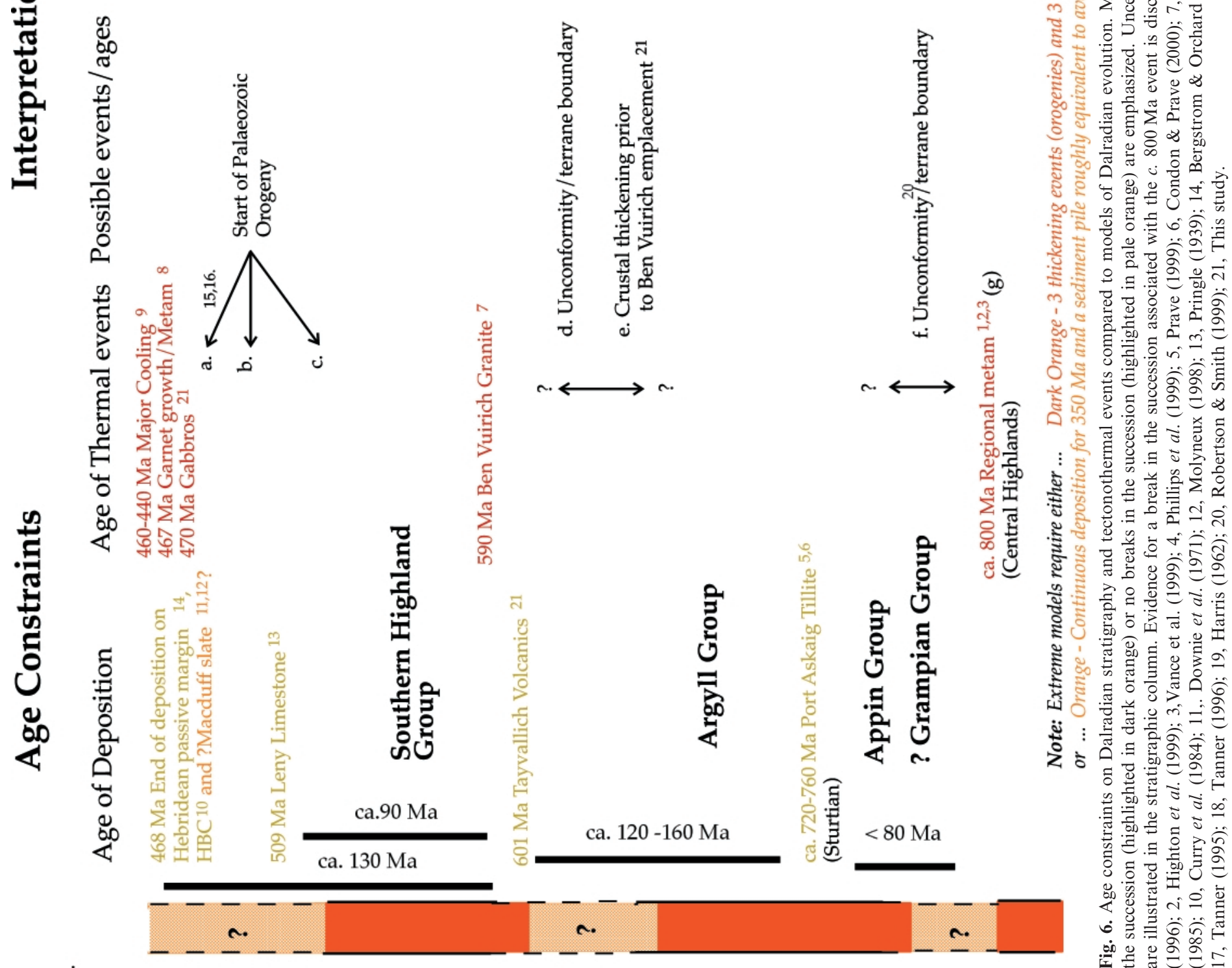
thickening very difficult to sustain. However, the lack of reliable age constraints throughout the Dalradian pile makes it difficult to know where to look for the evidence of breaks in the sequence. In part this problem may be because boundaries are represented by tectonic slides (e.g. Bailey 1922), and in part it may have resulted from an understandable desire to look for unity in mapping of both structures and stratigraphy. It seems most likely that the suggested crustal blocks are separated by tectonic boundaries, as orogenic unconformities would be easier to identify and also imply an intact chronostratigraphy, which seems improbable.

At present our preferred model (Fig. 6) would incorporate the following terrane boundaries, although we must emphasize that their locations are very poorly constrained and we would not wish to exclude the possibility of other equally well hidden breaks within the Dalradian stratigraphy.

(i) A Caledonian (pre-470 Ma) orogenic break between the Dalradian and the Ordovician rocks of the Highland Border Complex. Many have attributed a break at the Highland Border to the presence of the Highland Boundary Fault (e.g. Bluck 1984), whereas others have argued for structural continuity. Tanner \& Pringle (1999) argued for overall continuity up to the early Cambrian at Callander, although significant changes in provenance and rock chemistry were identified. Doing away with the need for continuous (600-470 Ma) deposition allows both a more reasonable timescale for Dalradian deposition and provides a little more time for the early stages of Caledonian orogenesis.

(ii) A late Precambrian (pre-590 Ma) orogenic break near the top of the Argyll Group. This thickening event would have produced relatively low-grade (greenschist-facies) regional metamorphism reaching a maximum grade in the Appin and Argyll group rocks of Central Perthshire (i.e. the earliest phase of the polymetamorphism in these areas). Higher-grade c. $800 \mathrm{Ma}$ assemblages of the Central Highlands are typically not significantly overprinted, but generally elsewhere Caledonian (470 Ma) metamorphic overprinting is very common.

\section{Discussion}

The deposition of Dalradian sediments in part coincides with an extreme global environment, possibly involving long-lived 'snowball' conditions (Hoffman et al. 1998; Prave 1999). Such an environment would be expected to have a profound influence on the depositional record within sediments formed at the time, and would create breaks in deposition within basins as precipitation ceased during which there may not even have been production of glacial tills (see Christie-Blick et al. 1999; Hoffman \& Schrag 1999). Whereas tills could conceivably mark the beginning and end of such 'snowball' periods, prolonged breaks in deposition may occur during these events and significant fractions of Dalradian history may be hidden here. This may be relevant to arguments about the apparently prolonged nature of deposition within, for example, the Southern Highland Group (i.e. post-Tayvallich volcanics (600 Ma) through to Leny Limestone at c. $508 \mathrm{Ma}$ ). Such conditions could also influence the nature of orogeny and cause difficulty in recognizing breaks within the Dalradian sequence. The absence of precipitation and erosion for a considerable period of time would mean that major unconformities could not be generated. Although crustal thickening could occur, subsequent thinning during continued 'snowball' conditions must occur by extension rather than erosion. The longer these global glaciations lasted, the greater chance there would be of orogens thinning without either a sedimentary record or major unconformities being produced. Perhaps the unusual nature of this period in Earth's history provides clues as to why the stratigraphic record within the Dalradian is so difficult to decipher.

Kenny Roberts, Robert Macdonald, Vincent Gallacher and Anne Kelly are thanked for technical assistance. Doug Fettes and Michael Flowerdew provided very helpful reviews of the manuscript. This work was supported by NERC grants GR3/7222 and GR3/9689. SUERC is supported by the Scottish Universities and the NERC. The gabbro samples were collected during work linked to the BGS East Grampian Mapping Project.

\section{References}

Ahmed-Said, Y. \& TAnner, P.W.G. 2000. P-T conditions during emplacement, and D2 regional metamorphism, of the Ben Vuirich Granite, Perthshire, Scotland. Mineralogical Magazine, 64, 737-753.

ANDERTON, R. 1985. Sedimentation and tectonics in the Scottish Dalradian. Scottish Journal of Geology, 21, 407-436.

Ashcroft, W.A., Kneller, B.C., Leslie, A.G. \& Munro, M. 1984. Major shear zones and autochthonous Dalradian in the north-east Scottish Caledonides. Nature, 310, 760-762.

Ashworth, J.R. 1985. The sillimanite zones of the Huntly-Portsoy area in the north-east Dalradian, Scotland. Geological Magazine, 112, 113-136.

BaiLeY, E.B. 1922. The structure of the south-west Highlands of Scotland. Quarterly Journal of the Geological Society of London, 78, 82-131.

Baldwin, S.L., Lister, G.S., Hill, E.J., Foster, D.A. \& McDougall, I. 1993. Thermochronologic constraints on the tectonic evolution of active metamorphic core complexes, D'Entrecasteaux Islands, Papua New Guinea. Tectonics, 12, 611-628.

BAKER, A.J. 1985. Pressures and temperatures of metamorphism in the eastern Dalradian. Journal of the Geological Society, London, 142, 137-148.

Beddoe-Stephens, B. 1990. Pressures and temperatures of Dalradian metamorphism and the andalusite-kyanite transformation in the northeast Grampians. Scottish Journal of Geology, 26, 3-14.

BELL, K. 1968. Age relations and provenance of the Dalradian Series of Scotland. Bulletin of the Geological Society of America, 79, 1167-1194.

Bergstrom, S.M. \& Orchard, M.J. 1985. Conodonts of the Cambrian and Ordovician Systems from the British Isles. In: Higgins, A.C. \& Austin, R.L. (eds) A stratigraphical index of conodonts. Ellis Horwood, Chichester. 32-67.

BLIss, G.M. 1977. The micropalaeontology of the Dalradian. PhD thesis, University of London.

Bluck, B.J. 1984. Pre-Carboniferous history of the Midland Valley of Scotland. Transactions of the Royal Society of Edinburgh: Earth Sciences, 75, $217-$ 228.

BLucK, B.J. \& Ingham, J.K. 1997. Discussion on New evidence that the Lower Cambrian Leny Limestone at Callander, Perthshire, belongs to the Dalradian Supergroup, and a re-assessment of the 'exotic' status of the Highland Border Complex. Geological Magazine, 134, 563-570.

Bluck, B.J., Dempster, T.J. \& Rogers, G. 1997. Allochthonous metamorphic blocks on the Hebridean passive margin, Scotland. Journal of the Geological Society, London, 154, 921-924.

Bradbury, H.J., Smith, R.A. \& Harris, A.L. 1976. 'Older' granites as timemarkers in Dalradian evolution. Journal of the Geological Society, London, 132, 677-684.

Bradbury, H.J., Harris, A.L. \& Smith, R.A. 1979. Geometry and emplacement of nappes in the Central Scottish Highlands. In: Harris, A.L., Holland, C.H. \& Leake, B.E. (eds) The Caledonides of the British Isles, Reviewed. Geological Society, London, Special Publications, 8, 213-220.

Brasier, M.D. \& McIlroy, D. 1998. Neonereites uniserialis from c. 600 Ma year old rocks in western Scotland and the emergence of animals. Journal of the Geological Society, London, 155, 5-12.

Brasier, M.D. \& Shields, G. 2000. Neoproterozoic chemostratigraphy and correlation of the Port Askaig glaciation, Dalradian Supergroup of Scotland. Journal of the Geological Society, London, 157, 909-914.

Brasier, M.D., McCarron, G., Tucker, R., Leather, J., Allen, P. \& Shields, G. 2000. New U/Pb zircon dates for the Neoproterozoic Gubrah glaciation and for the top of the Huqf Supergroup, Oman. Geology, 28, 175-178.

Brown, P.E., Miller, J.A., Grasty, R.L. \& Fraser, W.E. 1965. Potassiumargon ages of some Aberdeenshire granites and gabbros. Nature, 207, $1287-1288$.

Chinner, G.A. 1980. Kyanite isograds of Grampian metamorphism. Journal of the Geological Society, London, 137, 35-39.

Chinner, G.A. \& Heseltine, F.J. 1979. The Grampide andalusite/kyanite isograd. Scottish Journal of Geology, 15, 117-127. 
Christie-Blick, N., Sohl, L.E. \& Kennedy, M.J. 1999. Considering a Neoproterozoic Snowball Earth. http://www.sciencemag.org/cgi/content/full/ $284 / 5417 / 1087 \mathrm{a}$

CLIFF, R.A. 1985. Isotopic dating in metamorphic belts. Journal of the Geological Society, London, 142, 97-110

Condon, D.J. \& Prave, A.R. 2000. Two from Donegal: Neoproterozoic glacial episodes on the northeast margin of Laurentia. Geology, 28 , 951-954.

Corfu, F., Heaman, L.M. \& Rogers, G. 1994. Polymetamorphic evolution of the Lewisian complex, NW Scotland, as recorded by U-Pb isotopic compositions of zircon, titanite and rutile. Contributions to Mineralogy and Petrology, 117, 215-228.

Crowhurst, P.V., Hill, K.C., Foster, D.A. \& Bennett, A.P. 1996. Thermochronological and geochemical constraints on the tectonic evolution of northern Papua New Guinea. In: Hall, R. \& Blundell, D.J. (eds) Tectonic evolution of Southeast Asia. Geological Society, London, Special Publications, 106, 525-537.

Curry, G.B., Ingham, J.K., Bluck, B.J. \& Williams, A. 1982. The significance of a reliable Ordovician age for some Highland Border rocks in Central Scotland. Journal of the Geological Society, London, 139, 451-454.

Curry, G.B., Bluck, B.J., Burton, C.J., Ingham, J.K., Siveter, D.J. \& Williams, A. 1984. Age, evolution and tectonic history of the Highland Border Complex, Scotland. Transactions of the Royal Society of Edinburgh: Earth Sciences, 75, 113-133.

Dempster, T.J. 1985. Uplift patterns and orogenic evolution in the Scottish Dalradian. Journal of the Geological Society, London, 142, 111-128.

Dempster, T.J. \& Bluck, B.J. 1989. The age and origin of boulders in the Highland Border Complex: constraints on terrane movements. Journal of the Geological Society, London, 146, 377-379.

Dempster, T.J. \& Bluck, B.J. 1991. The age and tectonic significance of the Bute amphibolite, Highland Border Complex, Scotland. Geological Magazine, $128,77-80$.

Dempster, T.J. \& Harte, B. 1986. Polymetamorphism in the Dalradian of the central Scottish Highlands. Geological Magazine, 123, 95-104

Dempster, T.J., Hudson, N.F.C. \& Rogers, G. 1995. Metamorphism and cooling of the NE Dalradian. Journal of the Geological Society, London, 152, 383-390.

Dewey, J.F. \& Mange, M. 1999. Petrography of Ordovician and Silurian sediments in the western Irish Caledonides: tracers of a short-lived Ordovician continent-arc collision orogeny and the evolution of the Laurentian Appalachian-Caledonian margin. In: MacNiociall, C. \& Ryan, P.D. (eds) Continental tectonics. Geological Society, London, Special Publications, 164, 55-107.

Dewey, J.F. \& Pankhurst, R.J. 1970. The evolution of the Scottish Caledonides in relation to their isotopic age pattern. Transactions of the Royal Society of Edinburgh: Earth Sciences, 68, 361-389.

Downie, C., Lister, T.R., Harris, A.L. \& Fettes, D.J. 1971. A palynological investigation of the Dalradian rocks of Scotland. Institute of Geological Sciences, Reports, 71/9.

DunNing, G.R. \& KroGH, T.E. 1985. Geochronology of the ophiolites of the Newfoundland Appalachians. Canadian Journal of Earth Sciences, 22, $1659-1670$.

Elles, G.L. 1935. The Loch na Cille Boulder Bed and its place in the Highland succession. Quarterly Journal of the Geological Society of London, 91, 111-147.

England, P.C. \& Richardson, S.W. 1977. The influence of erosion upon the mineral facies of rocks from different metamorphic environments. Journal of the Geological Society, London, 134, 201-213.

Evans, D.A.D. 2000. Stratigraphic, geochronological, and paleomagnetic constraints upon the Neoproterozoic climatic paradox. American Journal of Science, 300, 347-433.

Evans, R.H.S. \& TAnNer, P.W.G. 1996. A late Vendian age for the Kinlochlaggan Boulder Bed (Dalradian)? Journal of the Geological Society, London, 153, 823-826.

Evans, R.H.S. \& TANner, P.W.G. 1997. Discussion on a late Vendian age for the Kinlochlaggan Boulder Bed (Dalradian)?: reply. Journal of the Geological Society, London, 154, 917-919.

FetTES, D.J. 1970. The structural and metamorphic state of the Dalradian rocks and their bearing on the age of emplacement of the basic sheet. Scottish Journal of Geology, 6, 108-118.

Fettes, D.J., Graham, C.M., Harte, B. \& Plant, J.A. 1986. Lineaments and basement domains: an alternative view of Dalradian evolution. Journal of the Geological Society, London, 143, 453-464.

Fettes, D.J., Leslie, A.G., Stephenson, D. \& Kimbell, S.F. 1991. Disruption of Dalradian stratigraphy along the Portsoy Lineament from new geological and magnetic surveys. Scottish Journal of Geology, 27, 57-73.

Friedrich, A.M., Bowring, S.A., Martin, M.W. \& Hodges, K.V. 1999a. Short-lived continental magmatic arc at Connemara, western Irish Caledonides: Implications for the age of the Grampian orogeny. Geology, 27, $27-30$.

Friedrich, A.M., Hodges, K.V., Bowring, S.A. \& Martin, M.W. 1999b. Geochronological constraints on the magmatic, metamorphic and thermal evolution of the Connemara Caledonides, western Ireland. Journal of the Geological Society, London, 156, 1217-1230.
Garson, M.S. \& Plant, J. 1973. Alpine type ultramafic rocks and episodic mountain building in the Scottish Highlands. Nature, 242, 34-38.

Goodman, S. 1994. The Portsoy-Duchray Hill Lineament: a review of the evidence. Geological Magazine, 130, 407-415.

Gower, P.J. 1977. The Dalradian rocks of the west coast of the Tayvallich peninsula. Scottish Journal of Geology, 13, 125-133.

Graham, C.M. 1986. The role of the Cruachan Lineament during Dalradian evolution. Scottish Journal of Geology, 22, 257-270.

Graham, C.M., Greig, K.M., Sheppard, S.M. \& Turi, B. 1983. Genesis and mobility of the $\mathrm{CO}_{2}-\mathrm{H}_{2} \mathrm{O}$ fluid phase during regional greenschist and amphibolite facies metamorphism: a petrological and stable isotope study in the Scottish Dalradian. Journal of the Geological Society, London, 140, $577-599$.

Gregory, J.W. 1931. Dalradian geology. Methuen, London.

Halliday, A.N., Graham, C.M., Aftalion, M. \& Dymoke, P.L. 1989. The depositional age of the Dalradian Supergroup: U-Pb and $\mathrm{Sm}-\mathrm{Nd}$ isotopic studies of the Tayvallich Volcanics, Scotland. Journal of the Geological Society, London, 146, 3-6.

Hambrey, M.J. 1983. Correlation of Late Proterozoic tillites in the North Atlantic region and Europe. Geological Magazine, 120, 209-320.

HARPER, C.T. 1967. The geological interpretation of potassium-argon ages of metamorphic rocks of the Scottish Caledonides. Scottish Journal of Geology, 3, 46-66.

Harris, A.L. 1962. Dalradian geology and the Highland Border near Callander. Bulletin of the Geological Survey of Great Britain, 19, 1-15.

Harris, A.J. \& Pitcher, W.S. 1975. The Dalradian Supergroup. In: Harris, A.L. (ed.) A correlation of Precambrian rocks in the British Isles. Geological Society, London, Special Reports, 6, 52-75

Harris, A.L., Bradbury, H.J. \& McGonigal, M.H. 1976. The evolution and transport of the Tay Nappe. Scottish Journal of Geology., 12, 103-113.

Harris, A.L., Haselock, P.J., Kennedy, M.J. \& Mendum, J.R. 1994. The Dalradian Supergroup in Scotland, Shetland and Ireland. In: Harris, A.L. \& Gibbons, W. (eds) A revised correlation of Precambrian rocks in the British Isles. Geological Society, London, Special Reports, 22, 33-53.

Harte, B. 1988. Lower Palaeozoic metamorphism in the Moine-Dalradian belt of the British Isles. In : Harris, A.L. \& FetTtes, D J. (eds) The CaledonianAppalachian Orogen. Geological Society, London, Special Publications, 38, 123-134.

Harte, B. \& Hudson, N.F.C. 1979. Pelite facies series and the temperatures and pressures of Dalradian metamorphism in E. Scotland. In: Harris, A.L., Holland, C.H. \& Leake, B.E. (eds) Caledonides of the British Isles - reviewed. Geological Society, London, Special Publications, 8, 323338.

Harte, B., Booth, J.E., Dempster, T.J., Fettes, D.J., Mendum, J.R. \& Watts, D. 1984. Aspects of the post-depositional evolution of Dalradian and Highland Border Complex rocks in the Southern Highlands of Scotland. Transactions of the Royal Society of Edinburgh: Earth Sciences, 75, 151163.

Henderson, W G. \& RoberTSON, A.H.F. 1982. The Highland Border rocks and their relation to marginal basin development in the Scottish Caledonides. Journal of the Geological Society, London, 139, 433-450.

Highton, A.J., Hyslop, E.K. \& Noble, S.R. 1999. U-Pb geochronology of migmatization in the northern Central Highlands: evidence for preCaledonian (Neoproterozoic) tectonometamorphism in the Grampian Block, Scotland. Journal of the Geological Society, London, 156, 11951204

Hoffman, P.F. \& Schrag, D.P. 1999. Response to Christie-Blick, N. et al. 1999. Considering a Neoproterozoic Snowball Earth. http://www.sciencemag. org/cgi/content/full/284/5417/1087a.

Hoffman, P.F. Kaufman, A.J., Halverson, G.P. \& Schrag, D.P. 1998. A Neoproterozoic snowball Earth. Science, 281, 1342-1346.

JAEGER, J.C. 1968. Cooling and solidification of igneous rocks. In: Hess, H.H. \& Poldervaart, A. (eds) Basalts. Wiley, New York, 503-536.

Jaffey, A.H., Flynn, K.F., Glendenin, L.E., Bentley, W.C. \& Essling, A.M. 1971. Precision measurement of half-lives and specific activities of ${ }^{235} \mathrm{U}$ and ${ }^{238}$ U. Physical Reviews, C, 4, 1889-1906.

James, R.S. \& Hamilton, D.L. 1969. Phase relations in the system $\mathrm{NaAlSi}_{3} \mathrm{O}_{8}$ $\mathrm{KAlSi}_{3} \mathrm{O}_{8}-\mathrm{CaAl}_{2} \mathrm{Si}_{2} \mathrm{O}_{8}-\mathrm{SiO}_{2}$ at 1 kilobar water vapour pressure. Contributions to Mineralogy and Petrology, 21, 111-141.

JoHANNES, W. 1984. Beginning of melting in the granite system Qz-Ab-Or-An$\mathrm{H}_{2} \mathrm{O}$. Contributions to Mineralogy and Petrology, 86, 264-273.

JoHnson, M.R.W. \& Harris, A.L. 1967. Dalradian-?Arenig relations in parts of the Highland Border, Scotland, and their significance in the chronology of the Caledonian orogeny. Scottish Journal of Geology, 3, 1-16.

Kaufman, A.J., Knoll, A.H. \& Narbonne, G.M. 1997. Isotopes, ice ages, and terminal Proterozoic earth history. Proceedings of the National Academy of Science, USA, 94, 6600-6605.

Kennedy, M.J., Runnegar, B., Prave, A.R., Hoffmann, C.H. \& Arthur, M.A. 1998. Two or four Neoproterozoic glaciations? Geology, 26, 10591063

Kerrick, D.M. 1991. Contact metamorphism. Reviews in Mineralogy, 26.

KNELLER, B.C. 1987. A geological history of north-east Scotland. In: Trewin, N.H., Kneller, B.C. \& Gillen, C. (eds) Geology of the Aberdeen area. Scottish Academic Press, Edinburgh. 1-50. 
Krogh, T.E. 1973. A low-contamination method for hydrothermal decomposition of zircon and extraction of $\mathrm{U}$ and $\mathrm{Pb}$ for isotopic age determination. Geochimica et Cosmochimica Acta, 37, 485-494.

KRoGH, T.E. 1982. Improved accuracy of U-Pb zircon ages by creation of more concordant systems using the air abrasion technique. Geochimica et Cosmochimica Acta, 46, 637-649.

Lindsay, N.G., Haselock, P.J. \& Harris, A.L. 1989. The extent of Grampian orogenic activity in the Scottish Highlands. Journal of the Geological Society, London, 146, 733-735.

LESLIE, A.G. 1987. Glens of Foudland: thermal metamorphic aureole of the Insch mass. In: Trewin, N.H., Kneller, B.C. \& Gillen, C. (eds) Geology of the Aberdeen area. Scottish Academic Press, Edinburgh. 171-178.

LoNG, L.E. 1964. Rb-Sr chronology of the Carn Chuinneag intrusion, Rossshire, Scotland. Journal of Geophysical Research, 69, 1589-1597.

LuDWIG, K.R. 1993a. ISOPLOT: a plotting and regression program for radiogenic-isotope data, version 2.60. United States Geological Survey Open-File Report, 91-445.

LudwIG, K.R. 1993b. PBDAT: a computer program for processing $U-P b-T h$ isotope data.. United States Geological Survery Open File Reports, 88-542.

Miall, A.D. 1990. Principles of sedimentary basin analysis. Springer-Verlag, New York.

Molyneux, S.G. 1998. An upper Dalradian microfossil reassessed. Journal of the Geological Society, London, 155, 740-743.

Muir, R.J., Ireland, T.R., Weaver, S.D. \& Bradshaw, J.D. 1996. Ion microprobe dating of Paleozoic granitoids: Devonian magmatism in New Zealand and correlations with Australia and Antarctica. Chemical Geology (Isotope Geosciences), 127, 191-210.

Noble, S.R., Hyslop, E.K. \& Highton, A.J. 1996. High precision U-Pb monazite geochronology of the $c .806 \mathrm{Ma}$ Grampian Shear Zone and the implications for the evolution of the Central Highlands of Scotland. Journal of the Geological Society, London, 153, 511-514.

Oliver, G.J.H., Chen, F., Buchwaldt, R. \& Hegner, E. 2000. Fast tectonometamorphism and exhumation in the type area of the Barrovian and Buchan Zones. Geology, 28, 459-462.

PANKhURST, R.J. 1970. The geochronology of the basic igneous complexes. Scottish Journal of Geology, 6, 83-107.

Parrish, R.R. 1987. An improved microcapsule for zircon dissolution in U-Pb geochronology. Chemical Geology (Isotope Geosciences), 66, 99-102.

Parrish, R.R. \& Krogh, T.E. 1987. Synthesis and purification of ${ }^{205} \mathrm{~Pb}$ for $\mathrm{U}-\mathrm{Pb}$ geochronology. Chemical Geology (Isotope Geosciences), 66, 103110 .

Pattison, D.R.N. \& TRACY, R.J. 1991. Phase equilibria and thermobarometry of metapelites. In: KerRICK, D.M. (ed.) Contact metamorphism. Mineralogical Society of America, Reviews in Mineralogy, 26, 105-206.

Phillips, E.R., Highton, A.J., Hyslop, E.K. \& Smith, M. 1999. The timing and $\mathrm{P}-\mathrm{T}$ conditions of regional metamorphism in the Central Highlands, Scotland. Journal of the Geological Society, London, 156, 1183-1193.

Piasecki, M.A.J. \& van Breemen, O. 1983. Field and isotopic evidence for a c. $750 \mathrm{Ma}$ tectonothermal event in the Moine rocks in the Central Highland region of the Scottish Caledonides. Transactions of the Royal Society of Edinburgh: Earth Sciences, 73, 119-134.

Pidgeon, R.T. \& Johnson, M.R.W. 1974. A comparison of zircon U-Pb and whole-rock $\mathrm{Rb}-\mathrm{Sr}$ systems in three phases of the Carn Chuinneag granite, northern Scotland. Earth and Planetary Science Letters, 24, 105-112.

Prave, A.R. 1999. The Neoproterozoic Dalradian Supergroup of Scotland: an alternative hypothesis. Geological Magazine, 136, 609-617.

Pringle, J. 1939. The discovery of Cambrian trilobites in the Highland Border rocks near Callander, Perthshire. Report of the British Association for the Advancement of Science, 1, 252.

Read, H.H. 1919. The two magmas of Strathbogie and Lower Banffshire. Geological Magazine., 56, 364-371.

Robertson, S. \& Smith, M. 1999. The significance of the Geal Charn-Ossian steep belt in the basin development in the Central Scottish Highlands. Journal of the Geological Society, London, 156, 1175-1182.

Rogers, G. \& Dunning, G.R. 1991. Geochronology of appinitic and related granitic magmatism in the W Highlands of Scotland: constraints on the timing of transcurrent fault movement. Journal of the Geological Society, London, 148, 17-27.

Rogers, G., Dempster, T.J., Bluck, B.J. \& Tanner, P.W.G. 1989. A high precision $\mathrm{U}-\mathrm{Pb}$ age for the Ben Vuirich granite: implications for the evolution of the Scottish Dalradian Supergroup. Journal of the Geological Society, London, 146, 789-798.
ShIELDS, G. 1999. Working towards a new stratigraphic calibration scheme for the Neoproterozoic-Cambrian. Eclogae Geologicae Helvetiae, 92, 221-233.

Skelton, A.D.L., Graham, C.M. \& Bickle, M.J. 1995. Lithological and structural controls on regional 3-D fluid flow patterns during greenschist facies metamorphism of the Dalradian of the SW Scottish Highlands. Journal of Petrology, 36, 563-586.

Soper, N.J., Ryan, P.D. \& Dewey, J.F. 1999. Age of the Grampian orogeny in Scotland and Ireland. Journal of the Geological Society, London, 156, 1231-1236.

Spencer, A.M. 1971. Late Pre-Cambrian glaciation in Scotland. Geological Society, London, Memoirs, 6.

STACEY, J.S. \& Kramers, J.D. 1975. Approximation of terrestrial lead isotope evolution using a two-stage model. Earth and Planetary Science Letters, 26, 207-221.

STEIGER, R.H. \& JÄGER, E. 1977. Subcommission on geochronology: convention on the use of decay constants in geo- and cosmo-chronology. Earth Planetary Science Letters, 36, 359-362.

Stewart, F.H. \& Johnson, M.R.W. 1960. The structural problem of the 'Younger Gabbros' of north-east Scotland. Transactions of the Edinburgh Geological Society, 18, 104-112.

TANNER, P.W.G. 1990. Structural age of the Connemara gabbros, western Ireland. Journal of the Geological Society, London, 147, 599-602.

TANNer, P.W.G. 1995. New evidence that the Lower Cambrian Leny Limestone at Callander, Perthshire, belongs to the Dalradian Supergroup, and a re-assessment of the 'exotic' status of the Highland Border Complex. Geological Magazine, 132, 473-483.

TANNER, P.W.G. 1996. Significance of the early fabric in the contact metamorphic aureole of the $590 \mathrm{Ma}$ Ben Vuirich Granite, Perthshire, Scotland. Geological Magazine, 133, 473-483.

TANner, P.W.G. \& Bluck, B.J. 1999. Current controversies in the Caledonides. Journal of the Geological Society, London, 156, 1137-1141.

TAnner, P.W.G. \& LesLie, A.G. 1994. A pre-D2 age for the 590 Ma Ben Vuirich Granite in the Dalradian of Scotland. Journal of the Geological Society, London, 151, 209-212.

TANner, P.W.G \& Pringle, M.S. 1999. Testing for the presence of terrane boundary within Neoproterozoic (Dalradian) to Cambrian siliceous turbidites at Callander, Perthshire, Scotland. Journal of the Geological Society, London, 156, 1205-1216.

Tavarnelli, E. \& Holdsworth, R.E. 1999. How long do structures take to form in transpression zones? A cautionary tale from California. Geology, 27, 1063-1066.

Thompson, R.N. 1981. Thermal aspects of the origin of Hebridean Tertiary acid magmas. I. An experimental study of partial fusion of Lewisian gneisses and Torridonian sediments. Mineralogical Magazine, 44, 161-170.

ToBisch, O.T. \& Fiske, R.S. 1982. Repeated parallel deformation in part of the eastern Sierra Nevada, California and its implications for dating structural events. Journal of Structural Geology, 4, 177-195.

Treagus, J.E. 1997. Discussion on A late Vendian age for the Kinlochlaggan Boulder Bed (Dalradian)? Journal of the Geological Society, London, 154, 917-919.

Treagus, J.E. \& Roberts, J.L. 1981. The Boyndie Syncline: a D1 structure in the Dalradian of Scotland. Geological Journal, 16, 125-135.

Tucker, R.D. \& McKerrow, W.S. 1995. Early Palaeozoic chronology: a review in light of new U-Pb zircon ages from Newfoundland and Britain. Canadian Journal of Earth Sciences, 32, 368-379.

van BREEMEN, O. \& BOYD, R. 1972. A radiometric age for pegmatite cutting the Belhelvie mafic intrusion, Aberdeenshire. Scottish Journal of Geology, 8 , $115-120$.

Vance, D., Strachan, R.S. \& Jones, K.A. 1998. Extensional versus compressional settings for metamorphism: Garnet chronometry and pressuretemperature-time histories in the Moine Supergroup, northwest Scotland. Geology, 26, 927-930.

WADSWORTH, W.J. 1970. The Aberdeenshire layered intrusion of north-eas Scotland. Special Publications of the Geological Society of South Africa, 1, $565-575$.

Wadsworth, W.J. 1982. The basic plutons. In: SutherLand, D.S. (ed.) The igneous rocks of the British Isles Wiley, Chichester, 135-148.

Wellings, S.A. 1998. Timing of deformation associated with the syn-tectonic Dawros-Currywongaun-Doughruagh Complex, NW Connemara, western Ireland. Journal of the Geological Society, London, 155, 25-37.

YARDLEY, B.W.D., BARBER, J.P. \& GRAY, J.R. 1987. The metamorphism of the Dalradian rocks of western Ireland and its relation to tectonic setting. Philosophical Transactions of the Royal Society of London, A321, 243-268. 